\title{
The geological and structural controls of gold mineralization in Qala en Nahal-Um Sagata region, South Gedarif, Sudan
}

\author{
Musab Awad Ahmed HASSAN ${ }^{1,2^{*}}$, \\ Aleksandr Evgen'yevich KOTEL'NIKOV ${ }^{1 * *}$ \\ ${ }^{1}$ Peoples' Friendship University of Russia (RUDN University), Moscow, Russia \\ ${ }^{2} \mathrm{Al}$ Neelain University, Khartoum, Sudan
}

\begin{abstract}
Relevance and purpose of the work. The study area is located in Gedarif state in Sudan. The ongoing work is aimed at solving fundamental problems of the geological structure of the Qala En Nahal-Um Saqata Ophiolitic Complex and applied tasks of mineral exploration. Detailed studies are being conducted for the first time in this area. The purpose of the investigation is to study the geological and structural features of the region, as well as to obtain information about the localization of gold mineralization.

Methods of research. Within the study area, a geological mapping of the ophiolitic complex was carried out. It's included an analysis of structural elements for investigation of the structural evolution and the phases of deformation. Chemical analysis of the mineralized quartz veins to determine the gold was carried out by Atomic Absorption Spectrometry (AAS) technique at the ALS Laboratory in Saudi Arabia.

Results of the work. The investigation of the structural evolution revealed at least three phases of deformation. The gold mineralization occurs in auriferous quartz veins, which are hosted in metavocano-sedimentary, sheared synorogenic granites and listvenites. The auriferous quartz veins are structurally controlled by dominantly NE main shear directions.

Conclusions. The gold mineralization in the area can be classified shear zone related mineralization, which is formed during the final event accomplished by crustal cooling, and formation of auriferous quartz vein along shear zones. Gold concentration were recorded in both quartz veins and associates alteration rocks. The area is promising for the presence of a gold deposit.
\end{abstract}

Keywords: Sudan, Qala En Nahal, Ophiolitic Complex, tectonics, structural evolution, gold, quartz vein.

\section{Introduction}

The study area is located some $70 \mathrm{~km}$ to the southeast of the Gedarif city, Gedarif State, in eastern Sudan near the border line between the Sudan and Ethiopia, between latitudes $13^{\circ} 15^{\prime}$ and $13^{\circ} 43^{\prime} \mathrm{N}$ and longitudes $34^{\circ} 45^{\prime}$ and $35^{\circ} 15^{\prime} \mathrm{E}$ (Fig. 1). It lies about $65 \mathrm{~km}$ to Gadarif town, $450 \mathrm{~km}$ SE Khartoum.

The area is part of Nubian Shield, a relatively under exploration that is known to host variable minerals including gold, Nickel, chrome and PGM. Gold has been extracted from the Nubian Shield of northeast Africa for over 5,500 years [1,2] from hundreds of ancient mines and, today, from extensive artisanal workings and eleven modern, operating or planned, large-scale mines [3]. Recently in the study are a numerous artisanal mining and mining companies at exploration stage are working. The aim of this study are to document the geology and structure of the area and gain insight into the setting and the nature of its hosted gold mineralization.

Regional geology

The Arabian Nubian Shield (ANS) in the north and the Mozambique Belt (MB) in the south, together, formed the East African Orogen (EAO). These two major terranes have a paramount key to understand the geodynamic and temporal evolution of the whole Pan-African orogeny in northeast Africa [4-8].
The Egyptian Eastern Desert, Sudan, western Saudi Arabia, Ethiopia, Eritrea, Jordan and Yemen belong to the socalled Arabian Nubian Shield, which formed during 900-550 Ma. Pan African event by modern type plate tectonic process. This involved accretion of intraoceanic arc/back arc complexes as well as continental micro plates [9]. The various terranes were welded together along ophiolite decorated sutures and finally collided with Nile Craton to the west [10-12] have defined a number of Late Proterozoic tectonic terranes across the Arabian-Nubian Shield. These comprise blocks of similar rock types separated by linear belts along which the ultramafic-mafic fragments are aligned.

Thrust faulting, shearing, mylonitization, and tectonic melange are characteristic of many contacts along which ophiolitic remnants are not always present [13].

\section{Local geology}

Um Saqata-Qala En Nahal area comprises as isolated hilly outcrops within intervening clay-covered plains. The area is consists mainly of supracrustal metasediments of medium-grade and a dominantly low-grade juvenile ophiolitic island-arc assemblage (Fig. 2). The ophiolitic fragments, known as Qala En Nahal-Um Saqata Ophiolitic Complex; 


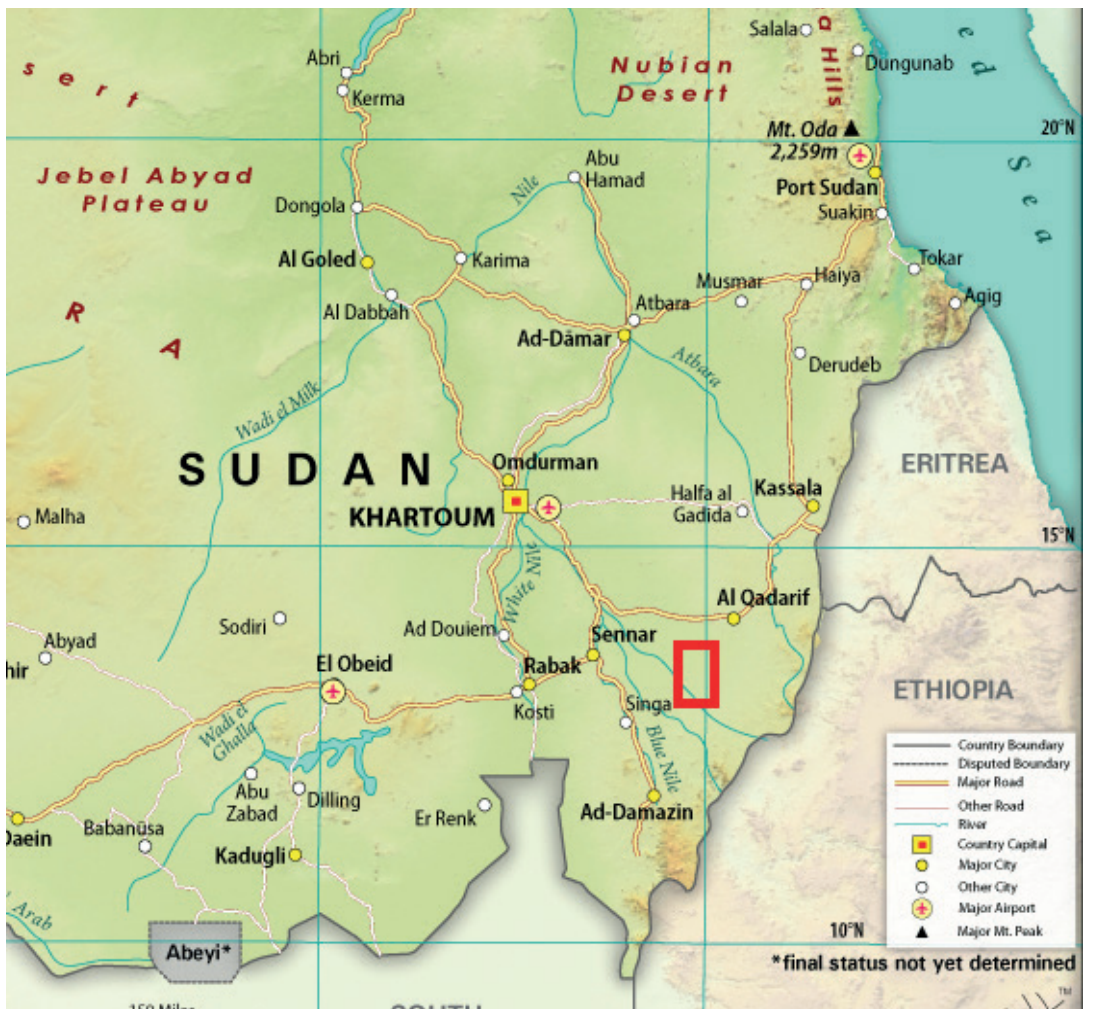

Figure 1. Location map of the study area (red outline).

Рисунок 1. Карта расположения района исследования (красный контур).

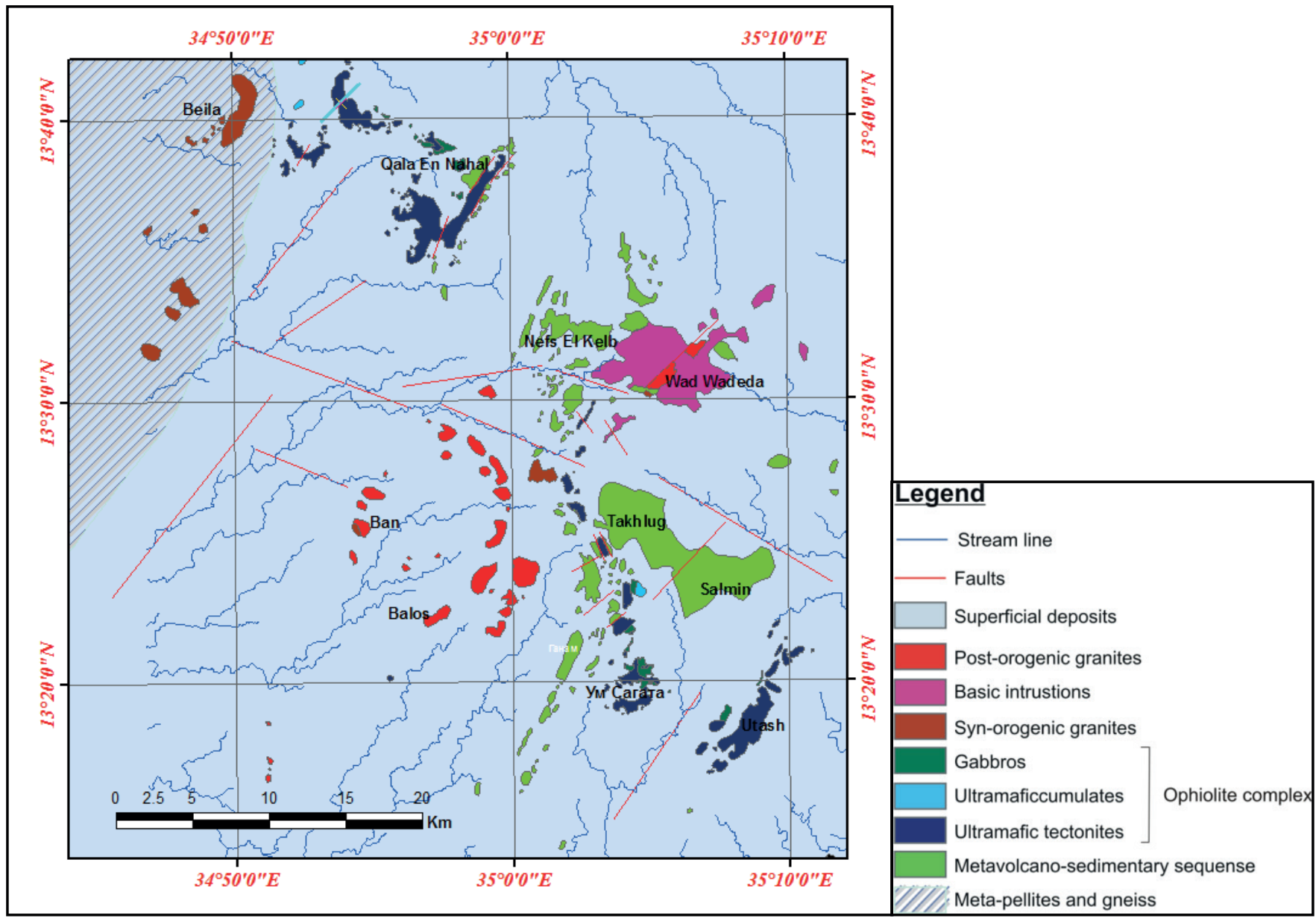

Figure 2. Local geological map of the study area.

Рисунок 2. Геологическая карта района исследования.

20 M. A. A. Hassan, A.E. Kotelnikov. The geological and structural controls of gold mineralization in Qala en Nahal-Um Sagata region, South Gedarif, Sudan//Известия УГГУ. 2020. Вып. 3(59). С. 19-26. DOI 10.21440/2307-2091-2020-3-19-26 

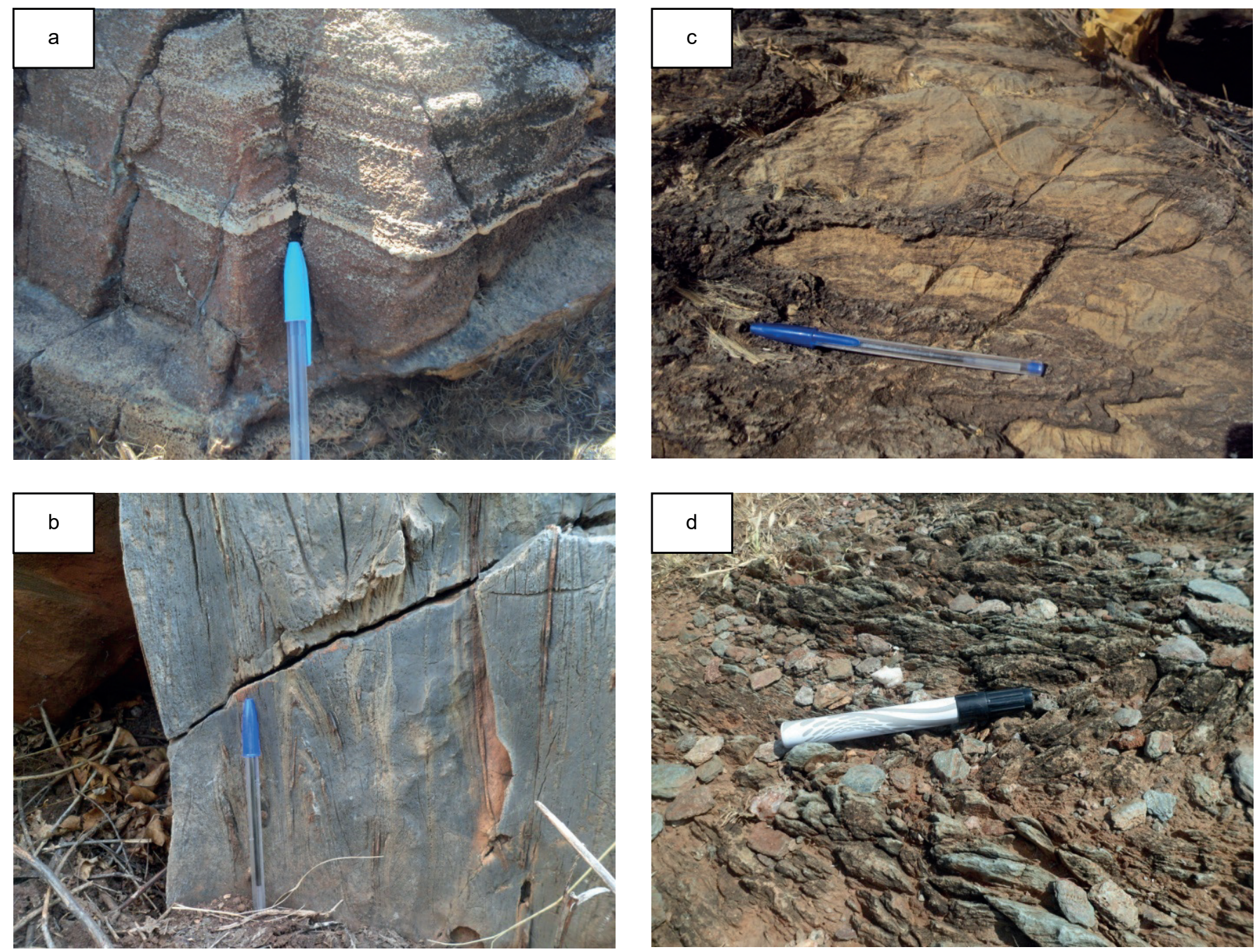

Figure 3: Macro photographs. a - rhythmic layering in cumulate gabbros; $b$ - tight isoclinals upright fold in marble; $c, d-r e c u m b e n t$ folds in marble and metavolcano-sedimentary respectively.

Рисунок 3. Макрофотографии: а - ритмическое наслоение в кумулятивных габбро; б - вертикальные изоклинальные складки в мраморе; в, г- лежачие складки в мраморе и метавулкано-осадочных породах соответственно.

structurally overlying, a layered sequence of low-grade Metavolcano-sedimentary units of predominantly late Proterozoic age.

Syn-orogenic and post-orogenic granites intrude the above-mentioned sequences. After these magmatic activities unconformable continental sedimentary sandstone Formations have been deposited on the basement rocks and subjected to extrusive basic volcanic eruptions. Recent and Quaternary deposits are manifested in the alluvial wadies deposits and recent Aeolian sand sheets.

The ophiolite complex is predominantly consists of serpentinites and gabbros. The serpentinites which have been altered to talc-magnesite rocks and listvenites.

The metavolcano-sedimentary unit is consist of a series of metamorphic complex rocks represented mainly by schists. They consists mainly of mica schist, graphite schist, chlorite schist and minor andalusite-quartz schist intercalated with quartzites and lenses of thin layered marbles. Metagraywacks and mtavolcanics are common.

The syn-orogenic granites are widespread in the study area, cutting all the previously described basement rocks. They are predominantly I-type granites. They consist of granites, granodiorites and tonalities. The rocks are medium to coarsegrained, foliated with widespread xenoliths.

The post orogenic intrusions occur as reddish rounded circular shape in satellite imagery, and represented by J. Ban, J. Balos, J. Bia, J. Buweida, J. Agharr, J. Shanqiya, J. El kambaros and J. Muraba.

\section{Methodology}

Beside the geological mapping of various rock units using remote sensing and GIS, reading of various structural elements include foliation, folding and shearing have been done. $\mathrm{Nu}$ mirous mineralized quartz veins and its alteration zone were documented and sampled for gold chemical analysis. The samples were submitted to ALS laboratories, Saudi Arabia using Atomic Absorption Spectrometry (AAS) technique.

Structural geology

Structurally, the study area is a part of the Nubian Shield, which is formed by accretion of island-arc, back-arc terranes and continental microplates during the Neoproterozoic (900$550 \mathrm{Ma}$ ) along E-NE-trending ophiolite decorated sutures [12, 14-16]. Major ductile shearing along strike-slip zones, transcurrent faulting and overriding tectonic forces from the east or southeast are believed to have caused the major NE-trending 
structures (folds and faults) in the various Red Sea Hills terranes [17-19]. Oblique to, and crosscutting these sutures, are younger (ca. 640-560 Ma) N-NW-trending left-lateral strikeslip shears such as Oko and Keraf Shear Zones [20, 21].

The structural geology of the study area will be described in regional framework. The area under investigation is dominantly consists of poly deforemed greenschist volcano-sedimentary sequences, ophiolitic complex and associated syn-orogenic granites.

The primary structures have been obscured by subsequence intense deformation, nevertheless, some primary structure $\left(\mathrm{S}_{0}\right)$ have been documented which includes bedding plane in metavolcano-sedimentary and rhythmic layering in cumulate gabbros (Fig. 3, a).

The investigation of the structural evolution revealed at least three phases of deformation $\mathrm{D}_{1}-\mathrm{D}_{3}$. Structural related to $\mathrm{D}_{1}$ deformation are represented by NE-SW tight isoclinals upright (Fig. 3, b) associated with low angle SE dipping trust folds and NW verging recumbent folds $\left(\mathrm{F}_{1}\right)$ (Fig.3, c, d). $\mathrm{D}_{1}$ deformation resulted in the development of strong penetrative $\mathrm{S}_{1}$ schistosity which represents the main planar fabric observed in the area. The $S_{1}$ foliation appears to be always parallel to the bedding $\mathrm{S}_{0}$. This phase is probably formed during closuring of the oceanic basin and collision between the ophiolite complex and metavolcano-sedimentary units onto the Sahara Meta Craton to the west (which represented by the amphibolites facies meta-pellitic schist and gneisses).

$\mathrm{D}_{2}$ folds $\left(\mathrm{F}_{2}\right.$ are generally of large scale tending NE. Folds are tight to open, upright (Fig. 4, a) with axial planes plunging to the NE. The $\mathrm{D}_{2}$ deformation is revealed by the refolding of the recumbent $\mathrm{D}_{1}$ folds $\left(\mathrm{F}_{1}\right)$. As a result of the interference of $\mathrm{F}_{1}-\mathrm{F}_{2}$ folds, mushroom-type interference patterns are formed (Fig. 4, b, c). The $\mathrm{S}_{2}$ crenulation cleavage in the metavolcano-sedimentary unit is probably related to this phase of deformation.

$\mathrm{D}_{3}$ deformation is represented by dominantly NE-ENE trending ductile dextral shear zone (Fig. 5) which is vertical to oblique with steep dip. $\mathrm{D}_{3}$ was probably formed due to the compression during oblique collision during regional shortening of the area. S3 foliation associated with D3 transposed S1 foliation by shear planes. Diffident kinematic indicators (e.g. porphyroblast and Z-shape structure interfolial folds) indicating dextral sense of shear movement (Fig. 6). Minor sinistral shear trending N-NW are present.

Gold mineralization

The gold mineralization occurs in auriferous quartz veins, which are hosted in metavolcano-sedimentary, sheared syn-orogenic granites and hydrothermally altered serpentinites (listvenites). These auriferous quartz veins are structurally controlled dominantly NE, with minor NNE and NW direction followed the main shear directions. Extensional shear fractures reflected in the brittle-ductile shear zones were broadly contemporaneous with the intense compressional tectonic regime. These fractures open spaces in which mineralizing fluids penetrated [22]. Therefore the gold mineralization in the study area can be classified shear zone related mineralization, which is formed during the final event accomplished by crustal cooling, and formation of auriferous quarz veins along shear zones. The source of the ore fluids is related to subduction and associated volcanic arc magmatism. These mineralized solutions
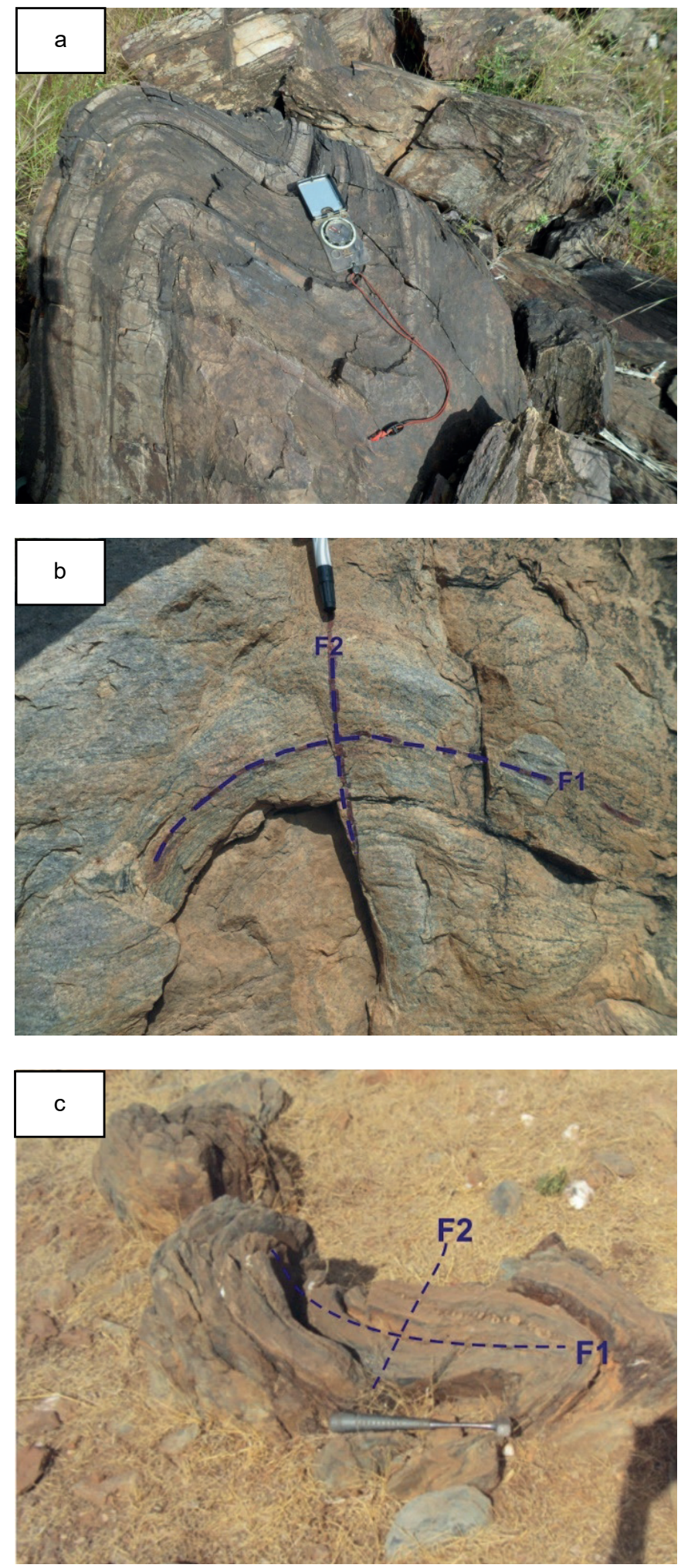

Figure 4. Macro photographs. $a$ - are tight to open, up-right fold; $b$, $c$ - mushroom-type interference patterns as a result of the interference of F1-F2 folds.

Рисунок 4. Макрофотографии: а - складки с правым сдвигом; b, c - грибообразные интерференционного вида, образованные в результате интерференции складок F1-F2.

are produced by metamorphism or cooling magmas [23]. The apparence of carbonates, kolinitized and sericitized alteration indicate a metamorphic origin and the metal contents formed from the leaching of host rocks during rock/water interactions. 


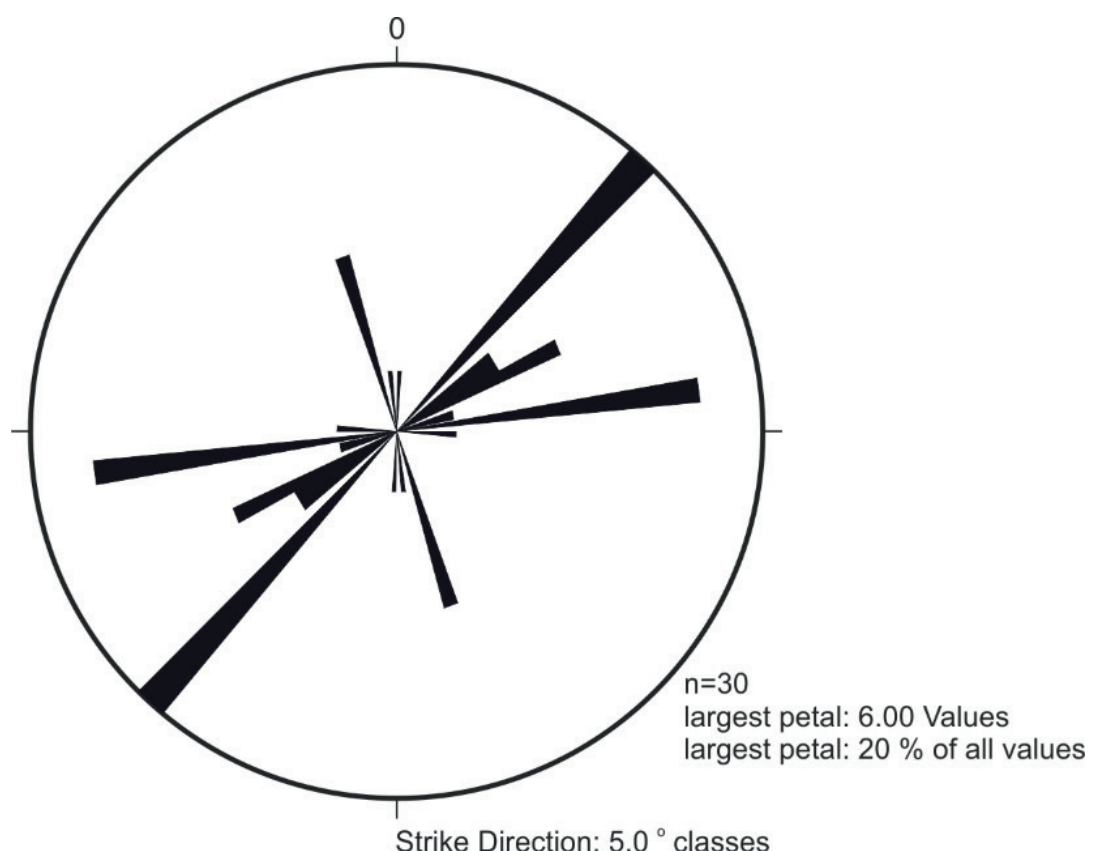

Figure 5. Rose diagram showing the distribution of shear trends at the study area.

Рисунок 5. Диаграмма направлений, показывающая распределение трендов сдвига на исследуемой территории.
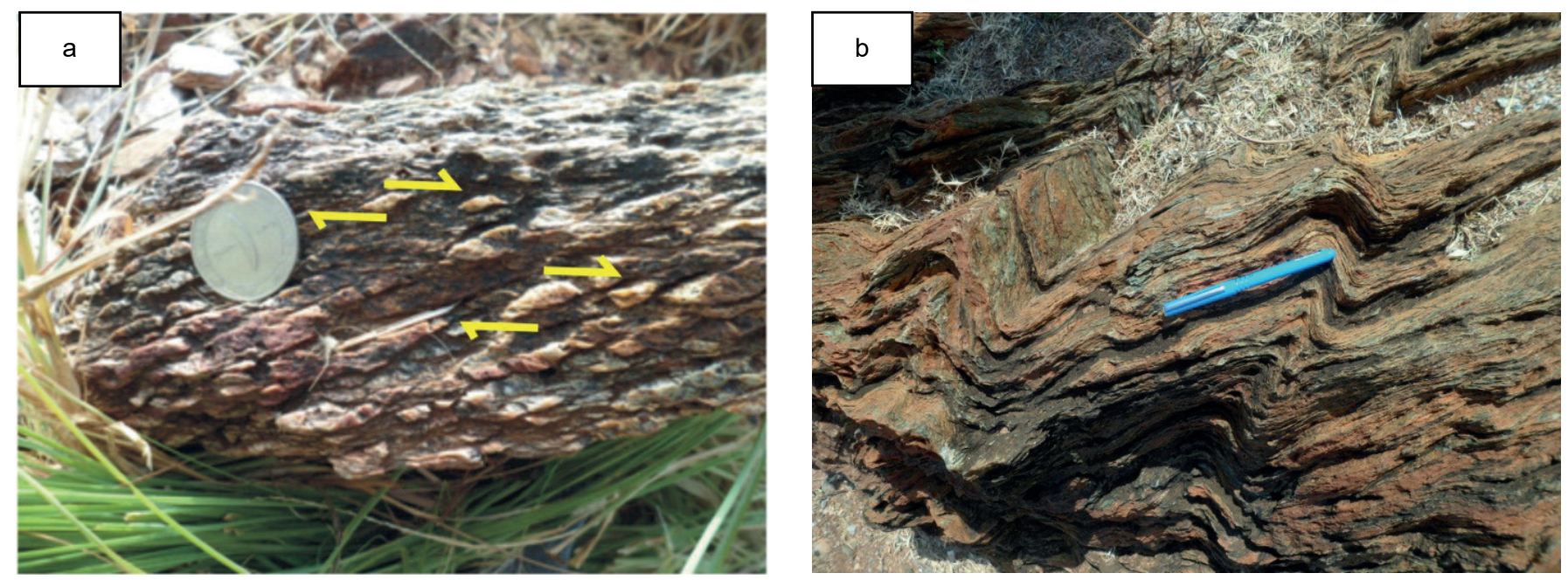

Figure 6. Macro photographs of Kinematic indicators of $D_{3}$ deformation indicating dextral sense of movement. a - rotated quartz porphyroclast in metavolcano-sedimentary; $b$ - Z-shape structure interfolial folds.

Рисунок 6. Макрофотографии кинематических показателей деформации $\mathrm{D}_{3}$, указывающие на правое смещение. а - повернутые кварцевые порфирокласты в метавулкано-осадочной породе; б - Z-образная структура складок.

The average contents of gold in quartz veins and associated alteration in various rock units, ppm.

Среднее содержание золота в кварцевых жилах и сопутствующих измененных породах в различных местах, г/т.

\begin{tabular}{lcc}
\hline \multicolumn{1}{c}{ Type of mineralization } & Numbers of analyzed samples & Average of gold, ppm \\
\hline Quartz-veins in listvenites & 8 & 0.18 \\
Alterations associated with listvenites & 7 & 1.77 \\
Quartz-veins in serpentinites & 6 & 0.03 \\
Quartz-veins in syn-orogenic granites & 5 & 7.77 \\
Quartz-veins in metavolcano-sedimentary & 37 & 1.34 \\
Alterations associated with metavolcano-sedimentary & 40 & 0.21 \\
\hline
\end{tabular}


The quartz veins are varying in colour, from reddish, white, gray, smoky to darck colour. The widths and lengths of the quartz veins are varying from few centimeters (stringers and veinlets) to 1 meter. The mineralized veins consist dominantly of quartz, with subordinate carbonates and sulphides. Sulphide are mainly pyrite, charcopyrite, galena and gersdorffite. Native golds occurs as minute crystals or flackes within the quartz veins. Gold concentration were recorded in both quartz veins and associates alteration rocks (Table).

\section{Conclusions}

The investigation of the structural evolution revealed at least three phases of deformation $\mathrm{D}_{1}-\mathrm{D}_{3}$. Structural related to $\mathrm{D}_{1}$ deformation are represented by NE-SW tight isoclinals upright associated with low angle SE dipping trust folds and NW verging recumbent folds. $D_{2}$ deformation is revealed by the refolding of the recumbent $\mathrm{D}_{1}$ folds $\left(\mathrm{F}_{1}\right)$. As a result of the interference of $\mathrm{F}_{1}-\mathrm{F}_{2}$ folds, mushroom-type interference patterns. $\mathrm{D}_{3}$ deformation is represented by dominantly NE-ENE trending ductile dextral shear zone

The gold mineralization occurs in auriferous quartz veins, which are hosted in metasediments, metavolcanics, sheared syn-orogenic granites and hydrothermally altered serpentinites (listvenites). These auriferous quartz veins are structurally controlled dominantly NE, with minor NNE and NW direction followed the main shear directions. Therefore the gold mineralization in the study area can be classified shear zone related mineralization, which is formed during the final event accomplished by crustal cooling, and formation of auriferous quartz veins along shear zones.

Gold concentration was recorded in both quartz veins and associates alteration rocks.

\section{REFERENCES}

1. Klemm D., Klemm R., Murr A. 2001, Gold of the Pharaohs - 6000 years of gold mining in Egypt and Nubia. Jornal of African Earth Sciences, vol. 33, issues 3-4, pp. 643-659. https://doi.org/10.1016/S0899-5362(01)00094-X

2. Klemm R., Klemm D., 2013. Gold and Gold Mining in Ancient Egypt and Nubia. Berlin; Heidelberg, Springer-Verlag, 649 p. https://doi. org/10.1007/978-3-642-22508-6

3. Johnson P. R., Zoheir B. A., Ghebreab W., Stern R. J., Barrie C. T., Hamer R. D. 2017, Gold-bearing volcanogenic massive sulfides and orogenicgold deposits in the Nubian Shield. South African Journal of Geology, vol. 120, issue 1, pp. 63-76. https://doi.org/10.25131/gssajg.120.1.63

4. Vail J. R. 1976, Outline of the Geochronology and Tectonic Units of the Basement Complex of Northeast Africa. Proceedings of the Royal Society of London. Series A, Mathematical and Physical Sciences, vol. 350, issue 1660, pp. 127-141. https://www.jstor.org/stable/79100

5. Kazmin V., Shifferaw A., Balcha T. 1978, The Ethiopian Basement: stratigraphy and possible manner of evolution. Geol. Resch., vol. 67, pp. 531-546. https://doi.org/10.1007/BF01802803

6. Bonavia F. F., Chorowicz J. 1992, Northward expulsion of the Pan-African of northeast Africa guided by a reentrant zone of the Tanzania craton. Geology, vol. 20, issue 11, pp. 1023-1026. https://doi.org/10.1130/0091-7613(1992)020<1023:NEOTPA>2.3.CO;2

7. Stern R. J. 1994, Arc assembly and continental collision in the Neoproterozoic East African Orogen: implications for the consolidation of Gondwanaland. Annual Review of Earth and Planetary Sciences, vol. 22, issue 1, pp. 319-351. http://www.annualreviews.org/doi/10.1146/ annurev.ea.22.050194.001535

8. Asrat A., Pierre B. 2003, Petrology, geochronology and Sr-Nd isotopic geochemistry of the Konso pluton, south-western Ethiopia: implications for transition from convergence to extension in the Mozambique Belt. International Journal of Earth Sciences, vol. 92, issue 6, pp. 873-890. https://doi.org/10.1007/s00531-003-0360-9

9. Kröner A., Greiling R., Reischman T., Hussein I. M., Stern R. J., Durr S., Kruger R., Zimmer M. 1987, Pan-African crustal evolution in the Nubian segment of Northeast Africa. In: Kröner A. (ed.). Proterozoic Lithosphere Evolution, Geodynamics Series. International Lithosphere Program contribution. American Geophysical Union, Washington, vol. 17, pp. 235-257. https://doi.org/10.1029/GD017p0235

10. Abdelsalam M. G., Dawoud A. S. 1991, The Kabus ophiolitic mélange, Sudan, and its bearing on the western boundary of the Nubian Shield. Journal of the Geological Society, vol. 148, issue 1, pp. 83-92. https://doi.org/10.1144/gsjgs.148.1.0083

11. Stoeser D. B., Camp V. E. 1985, Pan-African microplate accretion of the Arabian Shield. Geological Society of America Bulletin, vol. 96, issue 7, pp. 817-826. https://doi.org/10.1130/0016-7606(1985)96<817:PMAOTA>2.0.CO;2

12. Vail J. R. 1985, Pan-African (late Precambrian) tectonic terrains and the reconstruction of the Arabian-Nubian Shield. Geology, vol. 13, issue 12, pp. 839-842. https://doi.org/10.1130/0091-7613(1985)13<839:PLPTTA>2.0.CO;2

13. Kröner A. 1985, Ophiolites and the evolution of tectonic boundaries in the late Proterozoic Arabian-Nubian Shield of northeast Africa and Arabia. Precambrian Research, vol. 27, issues 1-3, pp. 277-300. https://doi.org/10.1016/0301-9268(85)90016-6

14. Stern R. J., Nielsen K. C., Best E., Sultan M., Arvidson R. E., Kröner A. 1990, Orientation of late Precambrian sutures in the Arabian-Nubian Shield. Geology, vol. 18, issue 11, pp. 1103-1106. http://dx.doi.org/10.1130/0091-7613(1990)018<1103:OOLPSI>2.3.CO;2

15. Kröner A., Stern R. J., Linnebacker P., Reischmann T., Manton W., Hussein I. M. 1991, Evolution of Pan-African island arc assemblages in the southern Red Sea Hills, Sudan as exemplified by geochemistry and geochronology. Precambrian Res., vol. 53, issues 1-2, pp. 99-118. https:// doi.org/10.1016/0301-9268(91)90007-W

16. Stern R. J., Kröner A. 1993, Late Precambrian Crustal Evolution in NE Sudan: Isotopic and Geochronologic Constraints. The Journal of Geology, vol. 101, issue 5, pp. 555-574. https://www.jstor.org/stable/30080152

17. Almond D. C., Ahmed F. 1987, Ductile shear zones in the northern Red Sea Hills, Sudan and their implication for crustal collision. Geol. Jour., vol. 22, issue S2, pp. 175-184. https://doi.org/10.1002/gj.3350220614

18. Almond D. C., Osman A. A., 1992. Relationships between shear zones and mineralization in the Nubian Shield of northeast Sudan. J. Unvi. Kuwait (Sci.), vol. 19, pp. 311-324.

19. Stern R. J., Kröner A., Manton W. I., Reischmann T., Mansour M., Hussein I. M. 1989, Geochronology of the late Precambrian Hamisana shear zone, Red Sea Hills, Sudan and Egypt. Journal of the Geological Society, vol. 146, issue 6, pp. 1017-1029. http://dx.doi.org/10.1144/ gsjgs.146.6.1017

20. Abdelsalam M. G. 1994, The Oko shear zone, Sudan: post-accretionary deformation in the Arabian-Nubian Shield. J. Geol. Soc., vol. 151, issue 5, pp. 767-776. https://doi.org/10.1144/gsjgs.151.5.0767

21. Abdelsalam M. G., Stern R. J., Copeland P., Elfaki E. M., Elhur B., Ibrahim F. M. 1998, The Neoproterozoic Keraf Suture in NE Sudan: Sinistral transpression along the eastern margin of west Gondwana. The Journal of Geology, vol. 106, issue 2, pp. 133-147. https://doi.org/10.1086/516012 22. Loizenbauer J., Neumayr P. 1996, Structural controls on the formation of the Fawakhir gold mine, EL Sid-Eastern Desert, Egypt: tectonic and fluid inclusion evidence. Proc. Geol. Surv. Egypt Cent. Conf., pp. 477-488.

23. Haraz Z. H. 2002, Fluid inclusions in the mesozonal gold deposits at Atud mine, Eastern Desert, Egypt. Journal of African Earth Sciences, vol. 35, issue 3, pp. 347-363. https://doi.org/10.1016/S0899-5362(02)00152-5 


\title{
Геологический и структурный контроль размешения золотой минерализации в районе Кала Эн Нахаиь-Ум Сагата, Южный Гедареф, Судан
}

\author{
Мусаб Авад Ахмед ХАССАН ${ }^{1,2^{*}}$, \\ Александр Евгеньевич КОТЕЛЬНИКОВ ${ }^{1 * *}$ \\ ${ }^{1}$ Российский университет дружбы народов (РУДН), Москва, Россия \\ 2Университет Аль-Нилен, Хартум, Судан
}

\section{Аннотация}

Актуальность и цель работь. Исследуемый район располагается в Судане, в штате Гедареф. Проводимые работы нацелены на решение фундаментальных вопросов геологического строения офиолитового комплекса Кала Эн Нахаль-Ум Сагата и прикладных задач по выявлению полезных ископаемых. Детальные исследования офиолитового комплекса проводятся впервые на данной территории. Целью данного исследования является изучение геологических и структурных особенностей района и получение информации об обстановке и характере размещения минерализации золота.

Методы исследования. В пределах исследуемой территории было проведено геологическое картирование офиолитового комплекса, включающее в себя анализ структурных элементов для установления структурной эволюции и выявления фаз деформации. Для определения золота был проведен химический анализ минерализованных кварцевых жил. Образцы были проанализированы методом атомно-абсорбционной спектрометрии (АAC) в лаборатории ALS в Саудовской Аравии.

Результаты выполненных исследований. Исследование структурной эволюции района офиолитового комплекса позволило выявить как минимум три фазы деформации. Золоторудная минерализация приурочена к кварцевым жилам, которые присутствуют в метавулкано-осадочных породах, рассланцованных синорогенных гранитах и лиственитах. Золотоносные жилы кварца структурно контролируются преимущественно зоной рассланцевания северо-восточного простирания.

Bbıоды. Установлено, что золотая минерализация в исследуемом районе связана с кварцевыми жилами, расположенными вдоль зоны дробления, которая образовалась в ходе тектонических процессов в последнюю стадию консолидации земной коры. Содержание золота было зафиксировано как в кварцевых жилах, так и в измененных породах. Данную территорию можно охарактеризовать как достаточно перспективную на наличие золота в промышленных масштабах.

Ключевые слова: Судан, Кала Эн Нахаль, офиолитовый комплекс, тектоника, структурная эволюция, золото, кварцевая жила.

\section{ЛИТЕРАТУРА}

1. Клемм Д., Клемм Р., Мурр А. Золото фараонов - 6000 лет добычи золота в Египте и Нубии // Журнал африканских наук о Земле. 2001. Т. 33, вып. 3-4. С. 643-659. https://doi.org/10.1016/S0899-5362(01)00094-X

2. Клемм Р., Клемм Д. Золото и золотодобыча в Древнем Египте и Нубии. Берлин; Гейдельберг: Springer-Verlag, 2013. 649 c. https://doi. org/10.1007/978-3-642-22508-6

3. Джонсон П. Р., Зохейр Б. А., Гебреаб В., Стерн Р. Дж., Барри К. Т., Хамер Р. Д. Золотоносные вулканогенные массивные сульфиды и месторождения орогенного золота на Нубийском щите // Южноафриканский журнал геологии. 2017. Т. 120, вып. 1. С. 63-76. https://doi. org/10.25131/gssajg.120.1.63

4. Вейл Дж. Р. Очерк геохронологии и тектонических структур комплекса фундамента Северо-Восточной Африки // Труды Лондонского королевского общества. Сер. А. Математические и фризические науки. 1976. Т. 350, вып. 1660. С. 127-141. https://www.jstor.org/stable/79100 5. Казмин В., Шифферау А., Балча Т. Эфиопский фундамент: стратиграфия и возможные пути развития // Международный журнал наук о Земле. 1978. T. 67. С. 531-546. https://doi.org/10.1007/BF01802803

6. Бонавиа Ф. Ф., Хорович Дж. Эмиграция на север панафриканской части северо-востока Африки, направляемая возвращающейся зоной кратона Танзании // Геология. 1992. Т. 20, вып. 11. С. 1023-1026. https://doi.org/10.1130/0091-7613(1992)020<1023:NEOTPA>2.3.CO;2 7. Стерн Р. Дж. Область формирования дуги и столкновение континентов в неопротерозойском Восточно-Африканском орогене: последствия для консолидации Гондваны // Ежегодный обзор наук о Земле и планетах. 1994. Т. 22, вып. 1. C. 319-351. http://www.annualreviews. org/doi/10.1146/annurev.ea.22.050194.001535

8. Асрат А., Пьер Б. Петрология, геохронология и изотопная геохимия Sr-Nd плутона Консо, юго-запад Эфиопии: последствия перехода от конвергенции к расширению в Мозамбикском поясе // Международный журнал наук о Земле. 2003. Т. 92, вып. 6. C. 873-890. https:// doi.org/10.1007/s00531-003-0360-9

Mmusabeljah78@gmail.com

https://orcid.org/0000-0003-2691-5703

"kotelnikov-ae@rudn.ru

(D) https://orcid.org/0000-0003-0622-8391

M. A. A. Hassan, A.E. Kotelnikov. The geological and structural controls of gold mineralization in Qala en Nahal-Um Sagata region, 25 South Gedarif, Sudan//Известия УГГУ. 2020. Вып. 3(59). C. 19-26. DOI 10.21440/2307-2091-2020-3-19-26 
9. Крёнер А., Грейлинг Р., Райшман Т., Хусейн И. М., Стерн Р. Дж., Дурр С., Крюгер Р., Циммер М. Панафриканская эволюция земной коры в Нубийском сегменте Северо-Восточной Африки / А. Крёнер (ред.) // Эволюция протерозойской литоссреры, серия геодинамики. Дополнение к Международной программе по литосфере. Американский геофизический союз. Вашингтон, 1987. Т. 17. С. 235-257. https:// doi.org/10.1029/GD017p0235

10. Абдельсалам М. Г., Давуд А. С. Офиолитический меланж Кабус, Судан, и его влияние на западную границу Нубийского щита // журнал геологического общества. 1991. Т. 148, вып. 1. С. 83-92. https://doi.org/10.1144/gsjgs.148.1.0083

11. Стоузер Д. Б., Кэмп В. Э. Панафриканская аккреция микроплит на Аравийском щите // Бюллетень геологического общества Америки. 1985. Т. 96, вып. 7. С. 817-826. https://doi.org/10.1130/0016-7606(1985)96<817:PMAOTA>2.0.CO;2

12. Вейл Дж. Р. Панафриканский (поздний докембрийский) тектонический ландшафт и реконструкция Аравийско-Нубийского щита // Геология. 1985. Т. 13, вып. 12. С. 839-842. https://doi.org/10.1130/0091-7613(1985)13<839:PLPTTA>2.0.CO;2

13. Крёнер А. Офиолиты и эволюция тектонических границ в позднем протерозое Аравийско-Нубийского щита Северо-Восточной Африки и Аравии // Докембрийские исследования. 1985. Т. 27, вып.1-3. С. 277-300. https://doi.org/10.1016/0301-9268(85)90016-6

14. Стерн Р. Дж., Нильсен К. К., Бест Э., Султан М., Арвидсон Р. Э., Крёнер А. Ориентация позднедокембрийских швов на Аравийско-Нубийском щите // Геология. 1990. Т. 18, вып. 11. С. 1103-1106. http://dx.doi.org/10.1130/0091-7613(1990)018<1103:OOLPSI>2.3.CO;2

15. Крёнер А., Стерн Р. Дж., Линнебакер П., Райшманн Т., Мантон В., Хусейн И. М. Эволюция панафриканских ассоциаций островных дуг в южной части холмов Красного моря, Судан, на примере геохимии и геохронологии // Докембрийские исследования. 1991. Т. 53, вып. 1-2. C. 99-118. https://doi.org/10.1016/0301-9268(91)90007-W

16. Стерн Р. Дж., Крёнер А. Эволюция земной коры в позднем докембрии Северо-Восточного Судана: изотопные и геохронологические условия // Журнал геологии. 1993. Т. 101, вып. 5. С. 555-574. https://www.jstor.org/stable/30080152

17. Алмонд Д. К., Ахмед Ф. Зоны пластичного сдвига в северной части холмов Красного моря, Судан, и их значение для столкновения земной коры // Геологический журнал. 1987. Т. 22, вып. S2. C. 175-184. https://doi.org/10.1002/gj.3350220614

18. Алмонд Д. К., Осман А. А. Взаимосвязь между зонами сдвига и минерализацией в Нубийском щите на северо-востоке Судана // Научный журнал Кувейтского университета. 1992. Т. 19. С. 311-324.

19. Стерн Р. Дж., Крёнер А., Мантон В. И., Райшманн Т., Мансур М., Хусейн И. М. Геохронология позднедокембрийской зоны сдвига Хамисана, холмы Красного моря, Судан и Египет // Журнал геологического общества. 1989. Т. 146, вып. 6. С. 1017-1029. http://dx.doi. org/10.1144/gsjgs.146.6.1017

20. Абдельсалам М. Г. Сдвиговая зона Око, Судан: постаккреционная деформация Аравийско-Нубийского щита // Журнал геологического общества. 1994. Т. 151, вып. 5. С. 767-776. https://doi.org/10.1144/gsjgs.151.5.0767

21. Абдельсалам М. Г., Стерн Р. Дж., Коупленд П., Эльфаки Э. М., Эльхур Б., Ибрагим Ф. М. Неопротерозойский шов Керафа в северо-восточной части Судана: синстральная транспрессия вдоль восточной окраины западной Гондваны // Журнал геологии. 1998. Т. 106, вып. 2. C. 133-147. https://doi.org/10.1086/516012

22. Лойзенбауэр Дж., Ноймайр П. Структурный контроль образования золотого рудника Фавахир, Эль-Сид - Восточная пустыня, Египет: свидетельства тектонических и фрлюидных включений // Труды конференции, посвященной столетию Египетской геологической службы, 1996. C. $477-488$.

23. Хараз 3. Х. Флюидные включения в мезозональных месторождениях золота на руднике Атуд, Восточная пустыня, Египет // Журнал африканских наук о Земле. 2002. Т. 35, вып. 3. С. 347-363. https://doi.org/10.1016/S0899-5362(02)00152-5 